fruit trees and pulses. He was little interested in systematic mycology, and was led astray in the identification of the difficult members of the genus Rhizoctonia with which he worked, but he effected a considerable advance in knowledge of their biology and morphology. Of recent years, his chief work was a study of the types of the important Indian pulse crop, pigeon pea (Cajanus indicus), with the object of breeding for resistance to the wilt disease caused by Fusarium vasinfectum; in this difficult problem, for the crop is extensively out-pollinated, he achieved a considerable measure of success. If the work can be carried to a conclusion it will be of great benefit to Indian agriculture, for the disease is extremely destructive and the parasite so completely infests the soil as to necessitate prolonged rotation if the crop is to yield an adequate harvest. Other work on similar lines has been in progress at Pusa under Dr. Shaw's control on a number of crops such as cereals, linseed, gram (Cicer arietinum) and other pulses, tobaceo and various fibre and oil seed crops ; continuity in such work is essential, and Dr. Shaw's untimely death will greatly accentuate the difficulties of carrying it on, already made serious by the aftermath of the earthquake.

Dr. Shaw, who was fifty years of age, was educated at St. Olave's Grammar School and the Royal College of Science, obtaining the A.R.C.S. and D.Sc. (London). He was made a C.I.E. in the King's birthday honours list of this year.

\section{Prof. Kikunaé Ikeda}

By the death of Prof. Kikunaé Ikeda on May 3, Japanese science loses one of its foremost students of chemistry. Some details concerning his life and work appear in the May issue of the Proceedings of the Imperial Academy, Tokyo. Prof. Ikeda, who was born on October 8,1864 , studied science at the University of Tokyo and graduated in 1889 . During the next seven years, he taught chemistry in the Tokyo Higher Normal School, where, both by his teaching and by the text-books that he published, he greatly assisted the general appreciation in Japan of the new science of physical chemistry.

In 1896, Ikeda was appointed assistant professor of chemistry in the University of Tokyo, in which capacity he came to Europe three years later for further study of physical chemistry. During his stay in Europe, he worked in Ostwald's laboratory, where, in collaboration with Bredig, he published important work on the poisoning of colloidal platinum catalysts. $\mathrm{He}$ also worked for a short time at the Davy Faraday Laboratory in London. On his return to Japan in 1901, he was appointed to a full professorship in chemistry, which he held for twenty-two years. During this time he was particularly occupied with the study of chemical kinetics and the theory of solutions. During this period he was appointed chief of the Chemistry Division of the Institute of Physical and Chemical Research, and he served also on the National Research Council of Japan.

On retiring from his professorship in 1923, Prof. Ikeda continued to take an active interest in chemistry. After a stay of seven years in Germany, he returned to Japan in 1931 and established a private laboratory where he studied various problems concerned with the applications of chemistry. The high esteem in which he was held was shown on his sixtieth birthday, when his friends and former pupils arranged a celebration and raised a large sum of money which, by his wish, was given to the Chemical Society of Japan for the extension of the scientific publications of the Society.

\section{Mr. F. S. Stacey}

WE regret to announce the death, on August 11, of Mr. Francis Samuel Stacey, one of the pioneers of radiotelegraphy, at the age of fifty-six years.

Mr. Stacey was a student of Finsbury Technical College, and joined Marconi's Wireless Telegraph Co., Ltd. (then known as The Wireless Telegraph and Signal Co., Ltd.), in July, 1899, at the age of twenty years. After a short period in the Company's works he was employed for some time in experimental work as an assistant to Marchese Marconi, and, in 1900 , was engaged in the execution of a contract for the installation of wireless on the whole fleet of Belgian cross-channel steamers. Shortly afterwards he was transferred to Marconi's Wireless Telegraph Company of Canada, where he remained until 1910, engaged in the construction of stations, experimental work, and the operation of the Glace Bay trans-Atlantic wireless station.

Between 1910 and $1912 \mathrm{Mr}$. Stacey was employed at the Marconi station at Poldhu in Cornwall in connexion with experimental work and development of long-range high-power stations which had their birth at Poldhu. From 1912 until 1914 he was acting chief of the Constructional Section of the Marconi Company, and in 1914 became chief of one of the contract sections which deals with the supply of every kind of commercial wireless telegraph apparatus. Among other things, his department of the Marconi Co. has been concerned with the execution of contracts for nearly all the broadcasting stations in England, and a very large number in Europe, Japan, South Africa, and South America.

Mr. Stacey was married in 1909 to Miss M. McLeod, a Canadian lady, and leaves a widow and two daughters.

WE regret to announce the following deaths :

Prof. Luigi Devoto, professor of industrial diseasos and director of the clinic of industrial diseases in the University of Milan, on July 22, aged seventy-two years.

Prof. Aubrey C. Grubb, professor of physical chemistry in the University of Saskatchewan, known for his work on the electrical activation of hydrogen and nitrogen gases, on July 29, aged fifty-two years.

Dr. H. A. D. Jowett, manager of the Wellcome Chemical Works, Dartford, an authority on medicinal alkaloids, on August 10, aged sixty-six years. 